\title{
The voices of John Phillips and John Stevens through the paratexts of the translations of Don Quijote and of Spanish chronicles of the conquest
}

\author{
Roberto A. Valdeón \\ Huazhong University of Science and Technology, China/University of \\ Massachusetts, USA/University of the Free State, South Africa \\ valdeon@uniovi.es
}

\begin{abstract}
This article studies the paratexts of the translations of Don Quijote into English by John Stevens and John Phillips, and of the translations of Brevisima relación de la destrucción de las Indias by John Phillips and Crónica del Perú by John Stevens. It draws on the work of Gérard Genette, who discussed the use of paratexts in literary studies, and applies it to the translations covered here in order to discuss the concepts of "voice" and "translatorial identity", as used by translation scholars. After introducing the relevance of paratexts in Translation Studies research, the article studies the titles, the dedications and the prefaces of the four translations, and argues that these texts showed that the two translators had different aims in mind: while John Phillips's agenda was first and foremost ideological, John Stevens was particularly interested in producing faithful renditions of the original works.
\end{abstract}

Keywords: paratexts, John Phillips, John Stevens, Don Quijote, translatorial identity

\section{Resumen}

Este artículo analiza los paratextos de las traducciones de Don Quijote al inglés de John

Phillips y John Stevens, así como de las traducciones de Brevísima relación de la destrucción de las Indias de John Phillips y de la Crónica del Perú de John Stevens. Se aplica del trabajo de Gérard Genette sobre los paratextos en obras literarias a las traducciones citadas con el objeto de estudiar los conceptos de "voz" e "identidad del traductor" utilizado con anterioridad por traductólogos. Tras argumentar la 
importancia de los paratextos en el estudio de las traducciones, el artículo se centra en los títulos, las dedicatorias y los prefacios de las cuatro traducciones. El análisis de estos textos demuestra que los traductores tenían objetivos diversos al llevar a cabo las traducciones: mientras que la agenda de Phillips era predominantemente política, John Stevens mostraba un interés en producir traducciones fieles a los trabajos originales.

Palabras clave: paratextos, John Phillips, John Stevens, Don Quijote, identidad del traductor

\section{Introduction}

Drawing on Alvstad's conceptualization of "voice" in Translation Studies (2013), this article will discuss the paratexts of two English versions of Don Quijote de la Mancha, translated by John Phillips and John Stevens. To this aim, this article will study the paratexts as contextual linguistic markers of the voices of the translators, paying particular attention to their translatorial identity, a term used by Tan (2012) to refer to the characteristics of translators as mediators. Tan posits that, although translators are responsible for their choices, they are also social entities defined by contextual factors that will affect those choices (2012: 17). For this study, I have selected the paratexts in the English versions of Don Quijote by John Phillips and by John Stevens because these two translators share one unique feature: they also translated chronicles of the Spanish conquest of the Americas and they did so from a very different ideological standpoint. In this sense, the study of the paratexts will throw light on the translatorial identity and political agendas of the translators. Thus, paratexts can reveal the role translators play within their society, and, consequently, can be used to foreground the implicit "translation pact" (Alvstad, 2014) between the translators and their intended readership, which implies that they "invite readers to read translated books as if they were originals, composed solely by one agent, the author" (2014: 282), regardless of the visibility and voices of the translators. This has implications for the relationship between the translator (and the other agents involved in the process of rendering an original text into a different language) and the target readership, as the latter will accept the former as a guide to the text that faithfully reproduces the original.

In addition to this, Don Quijote is a complex fictional work as regards the concept of voice. Alvstad posits that "a fictional text generally consists of a variety of voices. There is the voice of the implied authors, the voice(s) of one or several narrators and the voices of characters, which are generally filtered through the voice of the implied author and/or narrator" (2013: 208-209). In Don Quijote this is further complicated by the narrator's initial claim that the text was, in fact, a translation from an Arab source (identified as Cide Hamete Benegeli). This claim has allowed scholars to use 
Cervantes's novel as an example of what has been termed as fictitious translations or pseudotranslations (Pym, 2004: 98-99; Pursglove, 2011: 2). In Don Quijote the voices of the fictional author, the fictional translator and the implied author are inseparable, even if they are not presented as such. In this paper I am not particularly concerned with this feature of Cervantes's novel, which has intrigued not only researchers, but also writers such as Jorge Luis Borges, who, in 1939, wrote a short story entitled "Pierre Menard, autor del Quijote", in which he raised questions concerning the connection between translation and appropriation. Here I aim to consider the function of paratexts and the way in which they serve the English translators to present themselves as the true carriers of Cervantes's words, and whether paratexts can help us foreground the traits of Phillips's and Stevens's translatorial identities (individual and/or social). For that purpose, I will consider the paratexts of their translations of Don Quijote and those written for their versions of two chronicles of the Spanish conquest of the Americas.

\section{Paratexts in Translation Studies research}

In recent years, paratexts have become of great interest in Translation Studies research (Tahir-Gürçağlar, 2011, 2014; Munday, 2013; Pellat, 2013). Tahir-Gürçağlar has stressed the importance of "the verbal and visual material surrounding and presenting published translations" (2011: 113) for the study of translations. This view falls in line with Munday's assertion that paratexts can contribute to the understanding of the translatorial activity (2013: 125-126). Genette, who introduced the concept of paratext in his book Seuils ${ }^{1}$ in 1987, compared paratexts to a "vestibule", because they offer "the world at large the possibility of either stepping inside or turning back" (1997: 2). Paratexts can take the form of titles, subtitles, prefaces, dedications, notes and epilogues. In this article, I will examine three of these paratexts: 1) the titles, the subtitles and other material on the title pages, 2) the dedications, and 3) the prefaces. Although Genette makes a distinction between titles proper and title pages, here I will focus on the latter, as it typically includes the title plus some other relevant information for both the source and the target readers. Thus, title pages include the name of the author, the publisher, the address of the publisher, the name of the dedicatee, the date of publication and so on (Genette, 1997: 55). Genette notes that works of fiction may also provide a subtitle, which tends to give a more literal indication of the theme of the book (1997: 85). While titles have a descriptive function, they can also have a connotative one (Genette 1997: 89) depending on the way they are worded.

As regards dedications, Genette notes that their nature and features have evolved from its classical origins (1997: 117) to the present day. It is noteworthy that the

1 In this article I will use the English translation Paratexts: Thresholds of Interpretation. 
so-called dedicatory epistle was almost compulsory until the end of the eighteenth century. There was a reason for this: it was "regularly counted among a writer's sources of income" (1997: 119). Both John Phillips and John Stevens dedicated their works to high-ranking officials and aristocrats, who acted as their benefactors. On the other hand, Genette reminds us that Cervantes dedicated Don Quijote to the Duke of Béjar. This has been, in fact, the object of some controversy (for a discussion, see Calero, 2004). While Cervantes's dedication was very brief, what is interesting about the two English versions studied here is that they both have dedicatory epistles, that is, much longer texts where the translators resituated their own work within their own time. This will be discussed in detail below.

Finally, I will also consider the function of prefaces. As Tahir-Gürçağlar points out, we could assume that prefaces "inform readers about the text and its author in a manner of their choosing" (2014: 53). However, Tahir-Gürçağlar adds, the nature of a translation is often renegotiated by the translator, and the resulting version can, in fact, position itself in a "grey area between translation and original writing" (2014:56). Genette distinguishes between six types of prefaces, ranging from original authorial prefaces to fictional types (Genette, 1997: 196). In this paper, I will focus on Stevens's and Phillips's texts, understood as authorial prefaces of their own work as translators.

\section{John Philips and John Stevens, translators}

The English versions of Don Quijote de la Mancha by John Phillips (1687) and John Stevens (1700) occupy a prominent place in the history of the translations of Miguel de Cervantes's novel. Together with the texts by Shelton (his translation of the first part of the novel came out in 1612, and the second part in 1620; however, it is not clear whether Shelton translated both parts) and Peter Anthony Motteux (which appeared in 1700), Phillip's and Stevens's were the first English versions of the novel by Cervantes. There were other four translations during the same period, although these were abridged versions and, therefore, not so popular (see Megías and Ardila, 2009: 135-136). The complete unabridged English versions of Cervantes's novel enjoyed various degrees of success, although Shelton's and Motteux's texts were probably more popular than the two that will be studied here.

John Phillips's version is not considered a fully new translation of Don Quijote, but a revision of Thomas Shelton's text with some insights from the French translation by Filleau de Saint-Martin (Mayo and Ardila, 2009: 55). His version involved replacing Spanish names by English ones and adding coarseness to the original. The text was negatively received and "thirteen years after its publication, two translators were scandalized” (Nardo, 2014: 170). However, Nardo believes that Phillips's changes "do not 
violate narrative decorum" (2012: 4) because they exemplify what she calls his "modern skepticism" (Nardo, 2012: 15), which is reflected in the presentation of Don Quixote's love for the idealized Dulcinea. In addition, Nardo boldly claims that "Phillips goes after such medieval obscurantism and religious superstition with the zeal of an iconoclast" (2012: 15). This is, at best, mere speculation. In fact, most critics and translators have been far less tolerant of Phillips's style and choices. For instance, William Godwin, his nineteenth century biographer, described Phillips's version thus: "The liberties taken by him exceed upon the whole those of any translation I ever saw" (Godwin, 1815: 253).

On the other hand, John Stevens's rendition has been considered a slightly amended version of the translation by Shelton (Mayo and Ardila, 2009: 55), even though Stevens claimed that he strove to provide a faithful version of the original (Hayes, 2009: 67-68). This will be discussed in more detail below, as we consider the paratexts of the English versions of Don Quijote and of the Spanish chronicles they translated. As previously discussed (Valdeón, 2012a, 2012b, 2014a), John Phillips and John Stevens also translated two of the chronicles of the Spanish conquest of the Americas, namely Brevisima relación de la destrucción de las Indias in Phillips's case, and Crónica del Perú in Stevens's. This article aims to compare the extent to which the paratexts of these four works offer insights into their translatorial identity, i.e. whether we can trace an evolution and/or a divergence in the way they approached the translation of a literary work (i.e. Don Quijote) and of the chronicles, one of which was a pamphlet inspired by historical events (the Brevisima) while the other aimed to provide an accurate historical account of the conquest (the Crónica).

\section{The paratexts in John Phillips's and John Stevens's versions}

\subsection{The title pages}

John Phillips's version of Cervantes's novel was entitled The History of the most Renowned Don Quixote of Mancha: And his Trusty Squire Sancho Pancha (sic), while Stevens' translation came out as The History of the most Ingenious Knight Don Quixote de la Mancha. Both were published in London, the former in 1687 by Tho. Hodgkin. The title page also indicated, as it was customary at the time, that is was to be sold by some John Newton. The latter was published in two separate volumes in 1700, and it noted that it was printed for R. Chiswell, S. and J. Sprint, R. Battersby, S. Smith, B. Walford, M. Wotton and G. Conyers.

The title page offers two indications of the translators' different approaches to the novel. Stevens reminded his readers that his version was "formerly made English by 
Thomas Shelton, now revised, corrected, and partly new translated from the original", thus acknowledging the work of his predecessor. Additionally, Stevens, regarded by some as "probably the most careful of early Quixote translators" (Randall and Bosswell, 2009: xxvi), also indicated that two other people may have been involved in the translation process, but did not want to be mentioned ("two other persons, who desire to have their names concealed"). It is difficult to ascertain whether this was true or a strategy used by Stevens to neutralize any criticism of his work. In the second edition of the book, Stevens added that the translation had been "farther revised and amended".

Phillips, on the other hand, claimed that the novel was "made English according to the humour of modern language", thus suggesting that the translation was an adaptation of an original that was to follow the conventions of the English language, and, most significantly, that the aim was to please contemporaneous readers (Nardo, 2012, 2014: 175). However, the far-reaching changes carried out by Phillips were not to meet the expectations of future readers: the text has been considered one of the worst English versions of the work by Cervantes. Critics, researchers and translators have been very critical of his additions, modifications and omissions. Cunchillos, who wrote his doctoral thesis in the 1980s on the English translations of Don Quijote, stressed that the only method Phillips seemed to have applied to his work was the systematic distortion of the original (1986: 10). In fact, as Cunchillos reminded us, the fact that Phillips did not mention the name of the original author clarifies his position vis-à-vis the text. In this sense, Genette attaches great importance to the name of the author and the position in the title page. While Stevens clearly indicated that the text was "written in Spanish by Michael de Cervantes Saavedra", in Phillips's cover page the only voice that is clearly identified is that of the translator. Thus, although John Stevens occupied a much more prominent position than John Phillips, as his name was centrally located and was preceded by his title, Capt., Cervantes's name was places right after the title. This is relevant, as Genette notes, because the name of the translator is given prominence as the author of the English version while the use of the title reminded readers of his social position (1997: 40). Conversely, Phillips is only identified by his initials, J. P., but this should not deceive us: the translator identifies himself at the end of the dedicatory epistle: "My Lord, Your Lordships most humble, and most obedient servant. J. Philips". In fact, Phillips eliminated not only the name of the author, but also Cervantes's voice as a fictional translator as well as Cervantes's references to the weaknesses of his book as a translation. Instead, as Nardo reminds us (Nardo, 2014: 182), he inscribed himself into the text: "and may he never want Claret, as long as he lives, that translated it into English" (Cervantes 1687: 306), where "he" praises himself for translating the work into English. 
Phillips's approach to Don Quijote can hardly be regarded as a "rebellion against all the old hierarchies and modes of thought" (Nardo, 2014: 182). In fact, it falls very much in line with his approach to the translation of the Brevisima, where he also identified himself in the dedication, and used his initials in the cover page. The original title, Brevísima relación de la destrucción de las Indias, which could be translated literally as Brief Account of the Destruction of the Indies, had a double function: to attract the attention of the dedicatee, Crown Prince Philip of Spain, by means of a strongly expressive word, i.e. "destrucción", and also to provide a thematic description of the content of the book. In fact, the text was meant to be read only by Philip II, although it was later published and translated into several languages. For his own version, John Phillips altered the title and added a subtitle: Tears of the Indies, or Inquisition for Bloud: Being the Relation of the Spanish Massacre There. By doing this, the informative function was completely superseded by the connotative one, as the English title of Las Casas's work was a collection of evaluative and condemnatory words: tears, cruel, massacre, slaughters of innocent people, destruction. Published in 1656, Phillips appropriated Las Casas's book for his own critique of Spanish imperialism and, above all, to support his view that it should be replaced by an English empire (Valdeón, 2012a, 2014a, 2014b). To this aim, although Phillips was no faithful translator, he assured his readers that the book had been "written in Spanish by Casaus, an eye-witness of those things, and made English by J. P." It can hardly be argued that this was a rebellion against hierarchy, but rather a call to impose a different one.

As regards John Stevens's version of Cieza de León's Crónica del Perú, it was published in 1709 as The Seventeen Years Travels of Peter de Cieza through the Mighty Kingdom of Peru and the Large Provinces of Cartagena and Popayan in South America from the City of Panama, on the Isthmus, to the Frontiers of Chile. The title page did not include the name of the translator. Instead, it was indicated that the text was "Now translated from the Spanish, and illustrated with a map and several cuts". Thus, the overall effect is that of a factual presentation of the book to the readers. It also included the publication place and date. The name of the translator was included in the epistolary dedication: "Sir, Your most obedient and most devoted servant. John Stevens." In other words, in the translations of the chronicles, the authority of the translator is not established on the cover page. However, the "speaking agency" of the translator (Alvstad, 2014: 277 ) is reinforced through the epistolary dedications and the prefaces. This is done by transgressing a default situation of paratexts, that is, that the original books contained paratexts which were an integral part of the source texts (Alvstad, 2014: 277). For his part, Genette posits that dedications can also be written by translators (1997: 130). This will be discussed below. 


\subsection{The epistolary dedications}

As was customary at the time, all four texts begin with dedications to high officials. It may seem remarkable that translators followed the authorial habit of starting their work with this type of paratexts, but, as mentioned, this provided the translator with an additional source of income: "the dedication was generally a tribute that was remunerated, either by protection of the feudal type or by the more bourgeois (or proletarian) coin of the realm." (Genette, 1997: 119). Thus, Stevens devoted four pages of his Don Quijote to the "Honourable Sir Thomas Hanmer of the County of Flint, Bart", while the translation of Cieza de León's chronicle was dedicated to "the honourable Edmund Poley, of Badley in the country of Suffolk, Esq." In the former, Stevens wrote about the qualities of the work by Cervantes, paying particular attention to his critique of the books of chivalry because, Stevens noted, "served only to debauch youth, and infatuate old age with their impossible impertinences" (Cervantes, 1700: Dedicatory). Stevens himself was critical of those that had been incapable of understanding the value of Don Quijote, which he saluted as an "excellent and successful masterpiece", although he added that the translations had failed to capture "the beauty of the original". Surprisingly, Stevens's dedicatory epistle did not only aim to gain the favour of the dedicatee but was also an indictment of previous translations, which he considered "unpolished" and full of mistakes. His own translation, he claimed, attempted to address some of these problems. As we shall see below, Stevens also expanded on his translation efforts in the prefaces.

As regards his version of Crónica del Perú, Cieza de León's chronicle, it should be noted that Poley, the dedicatee, was also a member of a distinguished family, although his political connections were relatively unimportant. The dedicatory itself made two points: first, that it was customary to dedicate great works to worthy people and, therefore, Stevens stated that it would be "a fault to make use of none upon the like occasions"; second, that given the nature of the book, which dealt with the habits and customs of distant people with whom commercial relationships could be established, it should be dedicated to a deserving patron. Thus, by combining these two points, Stevens justified having "recourse to you, as to one above all exception" (Cieza de León, 1709: Dedicatory epistle).

For his part, Phillips had more influential benefactors in mind. He dedicated Don Quijote "To the Right Honourable William Earl of Yarmouth, Treasurer of His Majesties Household". Hanmer was a member a distinguished family based in North Wales, but had been educated in Oxford. He was also a Member of Parliament for his constituency (Biographia Britannica 1766: 222). The dedication to William Paston, the second earl of Yarmouth, reflects the political turmoil of the time as well as Phillips's political ambitions. Paston had close connections with the Catholic king James II, 
but later converted to Anglicanism. After that, he would not occupy similar positions again. In the dedication, Phillips reminded Paston that Don Quijote had been favoured by "personages of the most illustrious note in all the learned parts of Europe", and added that the work was dedicated to "your Lordship being equally eminent, if not superior to any of them" (Cervantes, 1867: Dedication).

The text is reminiscent of Phillips's dedicatory epistle in Tears of the Indies, which, thirty years earlier, he had dedicated to "His Highness, Oliver, Lord Protector of the Commonwealth of England, Scotland and Ireland with the dominions thereto belonging." However, this dedication was longer (seven pages as opposed to three for his English Don Quijote) and far more politicized. In Tears of the Indies, Phillips appropriated the voice of Las Casas, the author, to convince Oliver Cromwell of the need to attack the "bloody and popish nation of the Spaniards, whose superstitions have exceeded those of Canaan". In addition, Phillips expressed his admiration for Cromwell and reminded the Lord Protector of his divine duty: "Thanks to Almighty God, that you have made the land so happy, as to be the admiration of other nations, who have laid themselves at Your feet for alliances."

As can be seen, Phillips's dedications were clearly political, particularly the one in the Brevisima. Here Phillips replaced the dedication to the Spanish prince of the original by one addressed at Oliver Cromwell. Las Casas wanted to encourage the future king, Philip II, to take action against the conquerors in order to improve the situation of the native population in the Americas. Conversely, the translated version was a call for war against the Spanish. It might be argued that the dedication to Oliver Cromwell was part of Pillips's individual translatorial identity, as he was trying to gain favour with the Lord protector. However, Phillips's additions and modifications did not end here. He wrote a second dedication, which could be considered part of his social translatorial identity. In the second, and much longer, dedication, Phillips appealed "To all true Englishmen". As the country was plagued by religious rivalries, his voice became more violent: he encouraged his fellow countrymen to wage a war against the Spaniards. Indeed Phillips appealed to "all true Englishmen" on religious terms:

...the cruel slaughters and butcheries of the Jesuitical Spaniards, perpetrated upon millions of poor innocent heathens, who having only the light of nature, not knowing their Saviour Jesus Christ, were sacrificed to the political interest and avarice of the wicked Spaniards. (Phillips 1656: Dedication)

The tone is maintained in the whole dedication, with frequent references to the abominable crimes committed by the Spaniards and a critique of their actions as Christians: "but we now read of Christians, the professors of a religion grounded upon 
love and charity, massacring..." Las Casas had insisted on the fact that the conquerors did not behave like Christians. However, in the translation, Phillips replaced the word "cristianos" by "Catholick" or "Spaniards" (Valdeón 2012a). In order to further involve the readers in the narrative that he appropriated for his own purposes, Phillips's voice became that of a witness: "had you seen the poor creatures torn from the peace and quiet of their own habitations", thus replacing the voice of the original author (and alleged witness) by his own voice as an Englishman. Finally, the last part of this long dedication is an impassioned call for the English to fight the Spanish, "your old and constant enemies", who are described as "a proud, deceitful, cruel, and treacherous nation". To attract the readers' attention, the word is capitalized as "SPANIARDS" and readers are reminded of the Spanish attempts to invade England during the reign of Elizabeth I.

But, as mentioned, Phillips would change his tune when the times called for it. Years later, he would dedicate his translation of Don Quijote to a member of a distinguished family who converted to Catholicism and then back to Anglicanism, an example of the religious turmoil that characterized that period of English history. In fact, the dedication to the readers of Tears of the Indians, or to the true Englishmen, marks a sharp contrast with the phrase "Something instead of an epistle to the reader, by way of dialogue" that we find in Phillips's version of Don Quijote. This text, much shorter than the long dedication in Tears of the Indies, attempts to draw on the spirit of Cervantes's novel. It does so by introducing a long conversation between Amadis of Gaul and Don Quixote. However, the text bears no resemblance with the poems in Cervantes's work. The changes included the addition of characters such as the Knights of the Wandring Order, the Knight Templers, Olivers Porter, Betty Bully and the Alderman of Gotam, which might be part of Phillips's strategy to adapt the original to the tastes of the English readers (Cunchillos, 1986: 11), even if this meant the repositioning of the original novel.

As we compare the voices of the translators of the two English versions of Don Quijote and the two translations of the chronicles, we can conclude that the "translation pact" between readership and translators differed considerably. While Stevens presented his translations as faithful renderings of the source texts and showed respect towards the dedicatees, Phillips appropriated the original books and repositioned them within the target culture. This was accentuated in the translation of the chronicles, as his versions were presented as factual, as if written by the authors themselves (Alvstad, 2014: 271). In other words, they were supposed to be faithful reproductions of the source manuscripts. Consequently, while Stevens drew on the narrative of the original to write his dedication, Phillips used Las Casas's text as a political pamphlet against Spain and Cervantes's notes to meet the alleged expectations of the readership. 


\subsection{The prefaces}

Of the various prefaces mentioned by Genette, translators' prefaces are closer to the original authorial preface than any other type, that is, they can be defined as "authentic and assumptive" (1997: 196) in that they consist of "a discourse produced on the subject of the text that follows" (1997: 161) with a highly didactic component.

In Translation Studies, prefaces are a valuable source of information for the understanding of the translations and of the translatorial activity itself (Dimitriu, 2009; Munday, 2013). Dimitriu has stressed that prefaces can be useful for practitioners, trainees and TS researchers. For the latter, prefaces can function as "documents, case studies or complementary instruments providing clues to analysing the translators' actual behaviour" (Dimitriu, 2009: 201). In the light of the paratexts covered in this paper, one may add that the absence of prefaces can also provide insights into the work of the translators and the value attached to their work. In fact, the use of prefaces clearly distinguishes Stevens's and Phillips's translatorial identity. We have seen that, in the dedicatories, Stevens showed concern over his work as a translator. Stevens's preoccupation with the reception of his translations is reflective of his interest in the original texts, the language and the culture. In fact, it is noteworthy that Stevens translated Spanish fictional works, historical accounts, and was also the author of a Spanish-English dictionary and its corresponding grammar.

As regards his versions of Don Quijote and Crónica del Perú, Stevens identified himself as the translator in both cases. The former included a ten-page preface as well as a two-page "advertisement concerning the poetical part of the translation", in which he acknowledged that two other people had worked on the poetry, as he was not trained to do so himself: "The author of this translation, being himself unpractised in verse, thought fit to leave the poetry to two other person, who desire to have their names concealed" (Stevens, 1700: Preface). To distinguish the two hands, he added, "those pieces that are marked with a star are done by one hand, and the rest by another". That is, even if the translators remained anonymous, some degree of recognition was shown to them. Stevens's references to the quality of his own translation and the reception of the book can also be traced in his address to readers. He pointed out that he was not a master of Spanish and, therefore, it was necessary for him to have recourse to previous translations. This was a standard procedure at the time, although it was less common to admit it in a preface. Besides, Stevens told us, the translators of the various parts of Don Quijote also compared their work with the original "so that the reader may be satisfied of a fair version”.

The preoccupation with the reception of his work ran parallel to his honesty as a translator. In the preface, Stevens admitted that his voice would be heard in two 
distinct ways: on the one hand, as mentioned, he had consulted a previous translation to produce his own text; on the other, he made it clear that he had translated part of the original novel anew. He justified the changes on the basis that "the English was so antiquated or corrupt, and the meaning of Spanish so entirely lost, that I have been forced to translate sometimes half and sometimes whole pages" (Stevens 1700: Preface). In fact, Stevens argued, this version was superior to the two preceding English translations, the second being John Phillips's: Don Quixote "now comes abroad again to seek adventures, somehow more refined in language than the first time, and more like himself than the second" (Stevens 1700: Preface). By stating this, he implicitly suggested that John Phillips's version was an adaptation rather than an English version of the original work, although Hayes claims that Stevens somehow accepted Phillips's text as a translation, even if a loose one (Hayes, 2009: 67). However, it might also be that, given his concern with the reception of his work, Stevens phrased his critique of previous translations in such a way that it did not backfire, as he must have been aware of the risks of translating a foreign text of the stature of Don Quijote. Finally, he compared the work of the translator with the adventures of the hero of the novel: he spoke of the "enchanters that persecute them are ill-natured critics, whose only study is to discover or make faults in the works of others", while "they never can produce anything worth censuring" (Stevens, 1700: Preface).

The reception of his work was of great concern to Stevens, as the preface of Crónica del Perú attests (Valdéon 2012b: 577-578; 2014: 185). In the preface, Stevens showed his support for Cieza de León as a chronicler and as a soldier, and dismissed intersemiotic translations such as De Bry's visual representations of the Spanish conquest (for a detailed discussion see Valdeón 2012b). Stevens may have been "at odds to a certain extent with much of his contemporaries' discussions of translation, which since mid-century had emphasized the translator's relative freedom and creativity" (Hayes 2009: 67). In the prefaces, he spelt out his own approach to translation, irrespective of whether we call it fidelity to the original texts or we choose to present it in more negative terms. Stevens himself seemed ready to accept the latter:

I have endeavoured to follow the Spanish as close as ever the English would bear, not only in rendering the transactions exactly as represented; but in the very language and style, choosing rather to be blamed for adhering too servilly to my author, as it is generally termed, than to alter anything of his sense, which my chief aim is to reader as intelligible as may be, and yet to deliver it genuine without adulteration. (Stevens, 1700: Preface)

And yet, this does not have to be construed as entirely negative, but rather it could be interpreted as a critique of the two previous translations of Don Quijote, particularly Phillips's. Stevens aimed to dissociate himself from those who "alter the sense" and 
who "adulterate" the original text. In this sense, critics have applied words such as "travesty", "obscenity" and "buffoonery" to describe Phillips's version (Godwin, 1815: 254; Cunchillos, 1986). Stevens was very clear in this respect: "they [the techniques used by other translators] only corrupt and defame". He also added that he had not relied on the French translation, and stressed that rather than criticize the work of others, he preferred to explain his own choices concerning the style, i.e. he tried to imitate the heroic discourse of Don Quixote in his eloquent speeches as a knight errant, and remained more informal when translating his exchanges with other characters. Stevens also justified the preservation of certain names that English readers might be familiar with or, at least, be able to decipher, and explained that footnotes, another type of paratexts, were added whenever it seemed convenient: "because the meaning of them is not obvious to the English reader, I have explained by a note at the bottom of the page." Finally, he also devoted a long paragraph to explain the pronunciation of the Spanish names.

Stevens's approach to the translational endeavour should not be understood as complete faithfulness to the source. He accepted that his version could not follow the original in all instances. For instance, when translating proverbs he adopted a more functional approach, i. e. he opted for English equivalents that match the Spanish ones rather than translate them verbatim. In fact, in the preface of Crónica del Perú, Stevens admitted that he had made some important adjustments, and stated that "it is a vain presumption to expect to please all men, whose tempers and affections are so varied, that nothing can be found so universal as to be agreeable to them all. What one delights in, another loaths" (Stevens, 1709: Preface). After this, Stevens moved on to discuss the reasons why readers may dislike a certain literary work, although his final comments were optimistic: "it is hoped that this piece will may meet with a favourable reception, being recommended to the publishers of this collection by several gentlemen of unquestioned judgement". Stevens devoted the second part of the preface to express his admiration for Cieza de León, whom, he added, even the native writer Garcilaso de la Vega quoted in his chronicle of Peru. In Stevens's view, Cieza was in an excellent position not only to narrate the events that led to the conquest of the Andean region but also to describe its natural wonders, "which has never been so nicely done by any but Peter Cieza". However, Stevens did not provide details about his omissions, which have been displeased modern critics (León, 1973; Zaro, 2000). However, as I have noted (Valdeón, 2012), the omissions were probably motivated by what seemed to be his obsession to please his readers rather than as a result of his ideological stance.

For his part, Phillips did not mention other translators, nor did he comment on his own translational approach other than the statement on the cover page, i.e. "now 
made English according to the humour of our modern language". This could have led the readers to interpret his text as a retranslation aimed at adapting the original to contemporaneous English. However, as mentioned above, it was much more than that, as Phillips altered the original greatly. In addition, it seems that part of the book might have been rendered into English by other translators. Randall and Boswell have argued that an entry in the Register of the Worshipful Company of Stationers reports that the translation of the poetry was carried out by to several hands (Randall and Boswell, 2009: xxvi). Phillips did not mention this in the paratexts. Finally, he offered the readers a fascinating twist: he presented his translation as a Book-Errant, which allowed him to alter Don Quijote in many ways. As discussed, Phillips applied the concept of the ever-changing Book-Errant not only to his translation of Don Quijote but also to his English version of the tract by Las Casas.

\section{Concluding discussion}

Cecilia Alvstad has recently proposed the term "translation pact" (2014) to refer to the relationship of trust between translators and their readers. Bearing in mind that paratexts contribute to the creation and perpetuation of this bond, which "invites the reader to read the book as it were written only by the author" (2014: 271), I have examined how John Phillips and John Stevens created that bond by considering three types of paratexts in the English versions of Don Quijote and of two chronicles of the Spanish conquest of the Americas. The paratexts in the latter, as ideologically charged texts, have offered a complementary view of Phillips's and Stevens's very distinct translatorial identities.

As regards Don Quijote, critics such as William Godwin have received the translations of Cervantes's novel very differently. Godwin was particularly critical of Phillips's Don Quijote. He disliked what he called beastly allusions as well as the vulgar tone of the novel (1815: 253). Nardo, on the other hand, has recently undermined this critique by stating that Godwin could not speak Spanish. However, Godwin did not need to speak or read Spanish to be familiar with the negative reviews that had followed the publication of Phillips's text, nor did Godwin need to read Spanish to peruse other translations of Cervantes's novel, which were considered not merely more faithful to the words of the original, but, more importantly, to the spirit of the novel. In fact, Godwin recalled Shelton's version thus: "One of the finest passages in this incomparable monument of Spanish literature and genius, is the defense delivered by the shepherdess Marcella (...) This passage is beautifully given by Shelton" $(1815: 255)$. In contrast, Godwin commented, "John Phillips has interlarded this speech with his usual obscenity” (1815: 253). Godwin was writing about the English text. 
Nardo may be right in one respect. In Don Quijote, Phillips pursued his own agenda, even though whether the phrase "according to the humour of our modern language" reflected Phillips's endorsement of "the rejection of hierarchy and convention that was one project of his age" (Nardo, 2012: 19) is impossible to prove. Nor can we state for sure that Phillips used his work to attack credulity, superstition and radical religiosity (Nardo 2014: 172). This "humour of our modern language" is more likely to be indicative of the "skepticism and sexualized anti-Catholicism current in the print world of the 1670s and 1680s", as Nardo claims elsewhere (2012: 19). Back in the nineteenth century, Godwin had already stressed this feature in Phillips' work: for some of the writers of the period, "buffoonery, obscenity and ordure" were assumed to "be conducive to his purpose" (Godwin, 1815: 107). This seems to be a more accurate description of the voice of the translator, as shown in his social translatorial identity, whereby the anti-Catholic feeling was part and parcel of Phillips's ideological agenda, which he clearly and unashamedly spelled out in the two epistolary dedications of Tears of the Indies. Even those who regard Phillips in a more benevolent light have acknowledged that his "decidedly pro-national" identity stance was construed on the basis of his anti-papal, anti-Spanish, and anti-Dutch feelings (Shawcross, 2004: 124). This is the voice that permeates his translatorial identity. This voice might have attempted to undermine certain political and religious positions, as Nardo claims. However, this aim was far from noble, as his call for a war against the enemies of the English nation in the prefaces of Tears of the Indies absurdly equated the actions of the natives of Ireland to those of the Spanish in the Americas, while the English fighting in Ireland were compared to those of natives Americans being attacked by the Spanish!

In contrast, the translatorial identity of John Stevens, as the paratexts show, is that of a professional translator whose choices are based on his zeal to please his readers by means of adequate renditions and of a high degree of faithfulness to the authors' work. His social translatorial identity is also defined in these terms. While in his translation of Cieza de León's and Cervantes's work Stevens claimed to be faithful to the source texts, in the former he did not hide an ideological agenda of his own: by translating Crónica del Perú, he aimed to make his readership acquainted with the sufferings of the Spanish conquerors, who had "opened the way to other Europeans" (Stevens, 1709: Preface).

Finally, the study of these paratexts support Alvstad's critique of Genette, who regarded translations as paratexts (2014:273). The title pages, the prefaces and, above all, the dedications serve to establish a relationship with the target readers that can hardly be compared with that of the original authors and their own readership. Paratexts show that translations, at least in the case of highly polemical or exceptional works like the ones studied in this paper, are not merely linguistic transformations of 
a source text, even if they are presented as texts to be trusted, because the translators relocated the originals according to their own translatorial identities, vis-à-vis the society they belonged to as well as their own ideological stance.

\section{References}

Alvstad, C. (2013). Voices in translation. In Y. Gambier \& L. van Doorslaer (Eds.), Handbook of Translation Studies Volume 4 (207-210). Amsterdam: John Benjamins. . (2014). The translation pact. Language and Literature (23) 3: 270-284.

Biographia Britannica. Volume $6^{\text {th }}$ Part II. (1766). London: J. Walthow et. al.

Calero, F. (2013). Los duques de Béjar y El Quijote. Boletín de la Real Academia de Extremadura de las Letras y de las Artes XXI: 551-567.

Casas, B de las. (1656.) Tears of the Indies, or Inquisition for Bloud: Being the Relation of the Spanish Massacre There. London: J.C.

Cervantes, M. de. (1700). The History of the most Ingenious Knight Don Quixote de la Mancha. Translated by John Stevens. London: R. Chiswell at al.

(1687). The History of the most Renowned Don Quixote of Mancha: And his Trusty Squire Sancho Pancha. London: Tho. Hodgkin.

Cunchillos, C. (1986). Traducciones inglesas del Quijote: la traducción de Phillips (1687). Miscelánea 6: 3-20.

Dimitriu, R. (2009). Translators' prefaces as documentary sources for Translation Studies. Perspectives, (17) 3: 193-206.

Genette, G. (1997). Paratexts: Thresholds of Interpretation. Cambridge: Cambridge University Press.

Godwin, W. (1815). Lives of Edward and John Philips, Nephews and Pupils of Milton. London: Longman.

Hayes, J. C. (2009). Eighteenth-century English translations of Don Quixote. In J. A. G. Ardila (Ed.) The Cervantean heritage. Reception and influence of Cervantes in Britain (66-75). London: Modern Humanities Research Association \& Maney Publishing.

León, P. R. (1973). Algunas observaciones sobre Pedro Cieza de León y la crónica del Perú. Madrid: Gredos.

Lucía Megías, J. M. \& Ardila, J. A. G. (2009). The Much Esteemed History of the EverFamous Knight Don Quixote de la Mancha (1699). El éxito editorial de una traducción abreviada inglesa. Anales Cervantinos XLI: 135-165. 
The voices of John Phillips and John Stevens through the paratexts of the translations of Don Quijote and of Spanish chronicles of the conquest

Mayo, A. \& Ardila, J. A. G. (2009). The English Translations of Cervantes's Works across the Centuries. In Ardila, J. A. G. (Ed.) The Cervantean heritage. Reception and influence of Cervantes in Britain (54-60). London: Modern Humanities Research Association \& Maney Publishing.

Munday, J. (2013). The role of archival and manuscript research in the investigation of translator decision-making. Target 25: 125-139.

Nardo, A. K. (2012). John Phillips's translation of Don Quixote and 'the humour of our modern language'. Restoration: Studies in English Literary Culture, 1660-1700 36: $1-22$.

. (2014). John Phillips, John Milton, Don Quixote, and the disenchantment of romance. Mosaic: a Journal for the Interdisciplinary Study of Literature (47) 2: 169-186.

Pellatt, V. (Ed.) (2013). Text, Extratext, Metatext and Paratext in Translation. Newcastle upon Tyne: Cambridge Scholars Publishing.

Phillips, J. (1656). Dedicatory epistles. In Tears of the Indies, or Inquisition for Bloud: Being the Relation of the Spanish Massacre There. London: J.C.

Pursglove, G. (2011). Fakery, serious fun and cultural change: Some motives of the pseudo-translator. Hermeneus 13: 1-16.

Pym, A. (2004). The Moving Text. Localization, Translation, and Distribution. Amsterdam: John Benjamins.

Randall, D. B. J. \& Boswell, J. C. (2009). Cervantes in Seventeenth-Century England: the Tapestry Turned. Oxford: Oxford University Press.

Shawcross, J. T. (2004). The Arms of the Family. The Significance of John Milton's Realtives and Associates. Lexington: The University of Kentucky Press.

Stevens, J. (1700). Preface. In The History of the most Ingenious Knight Don Quixote de la Mancha. London: R. Chiswell at al.

Stevens, J. (1709). Preface. In The Seventeen Years Travels of Peter de Cieza through the Mighty Kingdom of Peru. London.

Tahir-Gürçağlar, S. (2011). Paratexts. In Y. Gambier \& L. van Doorslaer (Eds.), Handbook of Translation Studies Volume 2 (111-116). Amsterdam: John Benjamins.

. (2014). What texts don't tell: The use of paratexts in translation research. In Hermans. T (Ed.), Crosscultural Transgressions. Research Models in Translation Studies II: Historical and Ideological Issues (44-61). London: Routledge.

Tan, Z. (2012). The translator's identity as perceived through metaphors. Across Languages and Cultures 13: 13-32. 
Valdeón, R. A. (2012a). Tears of the Indies and the power of translation: John Phillips's version of Brevisima relación de la destrucción de las Indias. Bulletin of Spanish Studies (89) 6: 839-858.

. (2012b). Translation and the Crónica del Perú: The many voices of Pedro Cieza de León. Philological Quarterly 91: 569-590.

John Benjamins. (2014a). Translation and the Spanish Empire in the Americas. Amsterdam: . (2014b). The 1992 retranslation of Brevisima relación de la destrucción de las Indias. Translation Studies 7: 1-16.

Zaro, J. J. (2000). Translation and historical stereotypes: The case of Pedro Cieza de León's Crónica del Perú. TTR 13: 113-135. 